\title{
ANALISIS PERBANDINGAN KINERJA KEUANGAN SEBELUM DAN SESUDAH DIBERLAKUKANNYA TAX AMNESTY PERIODE PERTAMA PADA PERUSAHAAN SUB SEKTOR PROPERTY DAN REAL ESTATE YANG TERDAFTAR DI BEI
}

\author{
Anding Nugeraha ${ }^{1}$, I Gde Mandra ${ }^{2}$, I Nyoman Nugraha Ardana Putra ${ }^{3}$ \\ , andingnugeraha@gmail.com \\ sen Fakultas Ekonomi dan Bisnis Universitas Mataram, mandragede@yahoo.com \\ ${ }^{3}$ Dosen Fakultas Ekonomi dan Bisnis Universitas Mataram, ibobid@yahoo.com
}

\begin{abstract}
ABSTRAK
Penelitian ini bertujuan untuk (1) mengetahui kinerja keuangan sebelum dan sesudah tax amnesty periode pertama bila diukur dengan rasio keuangan berdasarkan angka standar industri pada perusahaan property dan real estate yang terdaftar di BEI, (2) menganalisis perbedaan kinerja keuangan sebelum dan sesudah diberlakukannya tax amnesty periode pertama pada perusahaan property dan real estate yang terdaftar di BEI. Populasi dalam penelitian ini adalah perusahaan sub sektor property dan real estate. Pengambilan sampel dilakukan dengan teknik purposive sampling dan diperoleh sebanyak 43 perusahaan sampel. Data yang digunakan adalah data sekunder berupa laporan keuangan triwulan II dan triwulan III tahun 2016 yang dipublikasikan melalui website www.idx.co.id dan www.sahamok.com. Pengujian hipotesis dilakukan dengan uji paired sample t-test. Hasil penelitian menunjukan bahwa kinerja keuangan sebelum dan sesudah tax amnesty periode pertama pada perusahaan property dan real estate yang diukur dengan rasio keuangannya yakni Current Ratio dan Debt to Equity Ratio tidak lebih baik dari standar industri, sedangkan Total Assets Turn Over dan Return On Equity lebih baik dari standar industri, terdapat perbedaan yang signifikan CR, TATO dan ROE antara sebelum dan sesudah diberlakukannya tax amnesty periode pertama, tidak terdapat perbedaan yang signifikan DER antara sebelum dan sesudah diberlakukannya tax amnesty periode pertama.
\end{abstract}

Kata kunci : Tax Amnesty, Current Ratio, Debt to Equity Ratio, Total Assets Turn Over, Return on Equity. 


\section{PENDAHULUAN}

Pajak merupakan sumber dana bagi pemerintah dalam menjalankan roda pembangunan nasional. Pembangunan nasional berlangsung secara terus menerus dan berkesinambungan guna mencapai kesejahteraan rakyat baik materil maupun spiritual. Untuk mencapai tujuan tersebut diperlukan anggaran pembangunan yang cukup besar. Salah satu usaha untuk mewujudkan peningkatan penerimaan untuk pembangunan tersebut adalah dengan menggali sumber dana yang berasal dari dalam negeri, yakni melalui pajak (Ngadiman, 2015). Sekarang ini pajak merupakan sumber penerimaan yang dominan dalam struktur anggaran penadapatan dan belanja negara (APBN). Hampir 70 persen penerimaan berasal dari sektor pajak.

Menurut data Direktorat Jenderal Pajak (DJP) Kementerian Keuangan, kinerja penerimaan pajak negara sepanjang Kuartal I tahun 2016 masih memprihatinkan. Realiasasi penerimaan pajak Januari-Maret 2016 baru mencapai Rp199,0 triliun atau sekitar 14,6 persen dari target pajak dalam APBN 2016. Jumlah ini malah menunjukkan penurunan Rp4,4 triliun dibanding Januari-Maret 2015 yang mencapai Rp203,4 triliun. Banyaknya potensi pajak yang sulit dijangkau pemerintah membuat target penerimaan pajak menjadi sangat berat. Sehingga diperlukan berbagai upaya-upaya nyata, serta diimplementasikan dalam bentuk kebijakan pemerintah untuk menggali penerimaan negara dari sektor perpajakan. Pemerintah tentu diharapkan dapat mempertimbangkan kembali kebijakan perpajakan yang bisa menarik minat masyarakat menjadi wajib pajak salah satunya yakni melalui tax amnesty (pengampunan pajak).

Dalam UU Nomor 11 tahun 2016, pasal 1, tax amnesty (pengampunan pajak) didefinisikan sebagai penghapusan pajak yang seharusnya terutang, tidak dikenai sanksi administrasi perpajakan dan sanksi pidana di bidang perpajakan, dengan cara mengungkapkan harta dan membayar uang tebusan. Tujuan diberlakukannya tax amnesty, yakni untuk meningkatkan likuiditas domestik, perbaikan nilai tukar, suku bunga yang kompetitif dan peningkatan Investasi melalui rapatriasi aset (Hand Out Materi Amnesty Pajak, Menteri Keuangan Direktorat Jendral Pajak, 2016). Beberapa kebijakan yang diterbitkan secara khusus untuk mengatur penerapan program tax amnesty di Indonesia diantaranya, Undang-undang (UU) Nomor 11 Tahun 2016 tentang Pengampunan Pajak yang disahkan pada tanggal 1 Juli 2016 oleh Presiden Republik Indonesia bapak Ir. H. Joko Widodo. Kemudian diikuti oleh Peraturan Menteri Keuangan (PMK) 118 Tahun 2016 tentang Pelaksanaan UU Pengampunan Pajak, dan PMK 119 Tahun 2016 tentang Tata Cara Pengalihan Harta Wajib Pajak ke NKRI dalam rangka pengampunan pajak. Pelaksanaan kebijakan ini secara efektif berlaku sejak tanggal 18 Juli 2016 hingga 31 Maret 2017 dan terbagi dalam tiga periode. Periode pertama dimulai dari 18 Juli hingga 30 September 2016, periode kedua dari 1 Oktober hingga 31 Desember 2016, dan periode ketiga dari 1 Januari hingga 31 Maret 2017.

Reformasi perpajakan yang diterapkan pemerintah saat ini melalui kebijakan tax amnesty tidak hanya berdampak terhadap peningkatan kapasitas fiskal semata, tetapi juga terhadap pertumbuhan ekonomi secara makro. Implementasi tax amnesty dengan tarif tebusan yang relatif rendah bagi dana repatriasi yang masuk ke Indonesia tentu saja memberikan dampak terhadap perushaan-perusahaan di Indonesia. Ketika kebijakan tax amnesty (pengampunan pajak) ini diterapkan oleh pemerintah melalui repatriasi aset, maka para pengusaha maupun waraga negara Indonesia yang memiliki harta diluar negeri dengan segera akan melaporkan harta yang dimilikinya dan menarik kembali ke Indonesia. Dengan kembalinya dana-dana tersebut ke dalam negeri menyebabkan 
sumber pendanaan maupun permodalan investasi di dalam negeri akan semakin tinggi dan perusahaan tidak akan mengalami kesulitan dalam mencari sumber-sumber pendanaan baru untuk melakukan pengembangan perusahaan. Sehingga kemungkinan hal ini dapat mempengaruhi kinerja suatu perusahaan.

Penelitian ini selanjutnya dilakukan untuk menganaliss kinerja keuangan perusahaan property dan real estate yang terdaftar di BEI sebelum dan sesudah diberlakukannya kebijakan tax amnesty periode pertama tahun 2016. Beberapa data berikut menyajikan informasi mengenai rata-rata perolehan laba 49 perusahaan property dan real estate periode tiga bulan sebelum dan tiga bulan sesudah di berlakukannya tax amnesty pada perusahaan yang terdaftar di Bursa Efek Indonesia. Perolehan laba perusahaan diklasifikasikan berdasarkan interval laba.

Berdasarkan Tabel 1. dapat kita ketahui bahwa pada interval laba pertama terjadi peningkatan jumlah perusahaan yang mengalami kerugian yakni dari 5 perusahaan sebelum tax amnesty menjadi 6 perusahaan pada sesudah tax amnesty dengan rata-rata kerugian yang justru mengalami penurunan dari sebesar Rp 22.246.576.335 menjadi Rp18.654.168. Selanjutnya jumlah perusahaan yang tertinggi (dominan) memperoleh laba terdapat pada interval laba kedua yakni masing-masing sebanyak 14 perusahaan baik sebelum maupun sesudah tax amnesty dengan laba rata-rata yang semakin meningkat. Apabila interval laba tersebut dibagi menjadi dua bagian yakni interval laba 1-6 dan interval laba 7-12, maka dapat diketahui bahwa jumlah perusahaan pada interval 1-6 menunjukan terjadinya penurunan yakni dari 34 perusahaan sebelum tax amnesty menjadi 28 perusahaan sesudah tax amnesty dengan laba rata-rata yang semakin meningkat yakni dari Rp17.081.939.909 menjadi Rp 20.890.962.715. Namun, sebaliknya pada interval laba 7-12 justru menunjukan terjadinya peningkatan jumlah perusahaan dari sebanyak 15 perusahaan sebelum tax amnesty menjadi 21 perusahaan sesudah tax amnesty dengan laba rata-rata yang mengalami penurunan dari sebesar Rp174.095.257.795 menjadi Rp113.679.872.425. Selanjutnya pada interval laba kedua belas jumlah perusahaan mengalami peningkatan dari 6 perusahaan sebelum tax amnesty menjadi 11 perusahaan pada sesudah tax amnesty yang diikuti pula dengan peningkatan terhadap laba perusahaan.

Sedangkan dari segi jumlah laba seluruh perusahaan property dan real estate antara sebelum dan sesudah tax amnesty menunjukan terjadinya penurunan yakni dari Rp3.214.461.400.161 menjadi Rp2.972.224.276.932. Begitu pula dengan laba rataratanya juga mengalami penurunan yakni dari Rp65.147.241.303 sebelum tax amnesty menjadi Rp60.657.638.305 sesudah tax amnesty. Oleh karena itu dari penjelasan diatas, dapat disimpulkan bahwa kinerja keuangan yang ditunjukan dengan perolehan laba pada perusahaan property dan real estate berbeda antara sebelum dan sesudah diberlakukannya tax amnesty periode pertama.

Tabel 1. Laba rata-rata berdasarkan interval perolehaan laba perusahaan periode 3 bulan sebelum dan 3 bulan sesudah tax amnesty

\begin{tabular}{|l|c|c|c|c|r|}
\hline \multirow{2}{*}{ No } & \multirow{2}{*}{$\begin{array}{c}\text { Interval Laba } \\
\text { (Dalam Miliar } \\
\text { Rupiah) }\end{array}$} & \multicolumn{2}{|c|}{3 bulan sebelum } & \multicolumn{2}{c|}{3 bulan sesudah } \\
\cline { 3 - 6 } & Jumlah & $\begin{array}{c}\text { Laba Rata-Rata } \\
\text { (Dalam Rupiah) }\end{array}$ & Jumlah & $\begin{array}{c}\text { Laba Rata-Rata } \\
\text { (Dalam Rupiah) }\end{array}$ \\
\hline 1. & $<0 \mathrm{M}$ & 5 & $(22.246 .576 .335)$ & 6 & $(18.654 .168 .451)$ \\
\hline 2. & $1-49,9 \mathrm{M}$ & 14 & 16.000 .017 .523 & 14 & 18.491 .773 .902 \\
\hline 3. & $50 \mathrm{M}-99,9 \mathrm{M}$ & 5 & 67.631 .004 .069 & 3 & 76.506 .077 .725 \\
\hline 4. & $100 \mathrm{M}-149,9 \mathrm{M}$ & 5 & 126.692 .514 .691 & 2 & 125.538 .891 .908 \\
\hline 5. & $150 \mathrm{M}-199,9 \mathrm{M}$ & 3 & 165.450 .322 .758 & 2 & 172.690 .189 .000 \\
\hline 6. & $200 \mathrm{M}-249,9 \mathrm{M}$ & 2 & 227.258 .674 .193 & 1 & 210.374 .191 .933 \\
\hline
\end{tabular}




\begin{tabular}{|l|c|c|r|c|r|}
\hline 7. & $250 \mathrm{M}-299,9 \mathrm{M}$ & 2 & 270.550 .432 .398 & 4 & 277.743 .530 .320 \\
\hline 8. & $300 \mathrm{M}-349,9 \mathrm{M}$ & 2 & 329.952 .618 .385 & 2 & 340.995 .716 .097 \\
\hline 9. & $350 \mathrm{M}-399,9 \mathrm{M}$ & 2 & 363.691 .547 .586 & 2 & 358.111 .428 .243 \\
\hline 10. & $400 \mathrm{M}-449,9 \mathrm{M}$ & 2 & 445.448 .998 .000 & - & - \\
\hline 11. & $450 \mathrm{M}-499,9 \mathrm{M}$ & 1 & 486.472 .041 .998 & 2 & 474.528 .251 .445 \\
\hline 12. & $>500 \mathrm{M}$ & 6 & 715.313 .228 .560 & 11 & 935.898 .394 .810 \\
\hline \multicolumn{2}{|r|}{ Jumlah } & $\mathbf{4 9}$ & $\mathbf{3 . 2 1 4 . 4 6 1 . 4 0 0 . 1 6 1}$ & $\mathbf{4 9}$ & $\mathbf{2 . 9 7 2 . 2 2 4 . 2 7 6 . 9 3 2}$ \\
\hline \multicolumn{2}{|r|}{ Rata-Rata } & & $\mathbf{6 5 . 1 4 7 . 2 4 1 . 3 0 3}$ & & $\mathbf{6 0 . 6 5 7 . 6 3 8 . 3 0 5}$ \\
\hline
\end{tabular}

Sumber: Laporan Keuangan Perusahaan Property dan Real Estate yang diolah.

Berikut disajikan pula rincian perolehan total dana tax amnesty pada periode pertama yang berlangsung sejak Juli hingga 30 September 2016 oleh wajib pajak yang mendeklarasikan asetnya di luar negeri melalui repatriasi dengan tarif sebesar $2 \%$ seperti pada tabel 2 .

Tabel 2. tersebut menunjukan rincian perolehaan dana di periode pertama tax amnesty. Berdasarkan surat pernyataan harta (SPH) dekelarasi harta pada periode pertama yakni sebesar Rp 3.620 triliun, dengan rincian, yakni deklarasi harta dalam negeri sebesar Rp 2.532 triliun, deklarasi harta luar negeri sbesar Rp 951 triliun dan dana repatriasi sebesar 137 triliun. Sedangkan untuk total uang tebusan berdasarkan SPH yang diterima Ditjen Pajak yakni sebesar Rp 89,1 triliun dengan rincian, yakni uang tebusan WP pribadi non UMKM sebesar Rp 76,6 triliun, uang tebusan dari WP badan non UMKM sebesar Rp 9,t triliun, uang tebusan dari WP orang pribadi UMKM sebesar Rp 2,63 triliun serta uang tebusan WP badan UMKM Rp 180 miliar. Kementerian Keuangan mencatat, baru sekitar 5.304 wajib pajak dari kalangan pelaku usaha property dan real estate yang telah mengikuti program pengampunan pajak dengan total nilai tebusan Rp3.070, 89 miliar.

Tabel 2. Rincian perolehaan dana tax amnesty periode pertama

\begin{tabular}{|c|c|c|}
\hline Keterangan & $\begin{array}{c}\text { Jumlah Dana } \\
\text { (Dalam Triliun Rp) }\end{array}$ & $\begin{array}{c}\text { Total Dana } \\
\text { (Dalam Triliun Rp) }\end{array}$ \\
\hline Dekelarasi Harta: & \multicolumn{2}{|}{3} \\
\hline Harta Dalam Negeri & 2.532 & \multirow{2}{*}{3.620} \\
\hline Harta Luar Negeri & 951 & \multirow{2}{*}{89.11} \\
\hline Repatriasi & 137 & \\
\hline Uang Tebusan: & 76,6 & \\
\hline WP Pribadi Non UMKM & 9,7 & \\
\hline WP Pribadi UMKM & 2,63 & \\
\hline WP Badan UMKM & 0,18 & \\
\hline
\end{tabular}

Sumber : Data statistik Ditjen Pajak, http://pajak.go.id/statistik-amnesti

Selain itu, berikut disajikan data penerimaan uang tebusan dari pelaku usaha property dan real estate yang tergabung dalam Persatuan Perusahaan Real Estat Indonesia (REI) yang mengikuti perogram pengampunan pajak (tax amnesty) akhir periode pertama dan sebaran di seluruh Indonesia seperti pada tabel 3. Tabel 3. Tersebut menunjukan data dari Kementerian Keuangan bahwa hanya 41\% dari kalangan komisaris perusahaan property dan real estate yang telah mengikuti pengampunan pajak dari total 6.044 WP. Selain itu, dari jajaran direksi tercatat ada $7.858 \mathrm{WP}$, tetapi baru $47 \%$ yang telah mengikuti program pengampunan pajak. Dari kalangan pemegang saham pun baru $49 \%$ yang telah mengikuti pengampunan pajak dari total $13.118 \mathrm{WP}$. 
Tabel 3. Data penerimaan uang tebusan pelaku usaha real estate beserta wilayah sebaran wajib pajak (WP) periode pertama.

\begin{tabular}{|c|l|l|c|}
\hline No & \multicolumn{1}{|c|}{ Wilayah Sebaran WP } & \multicolumn{1}{c|}{ Jumlah WP } & Nilai Tebusan \\
\hline 1 & Sulawesi & 133 & 46,84 miliar \\
\hline 2 & Nusa Tenggara - Papua Maluku & 57 & 320,8 miliar \\
\hline 3 & Kalimantan & 139 & 26,2 miliar \\
\hline 4 & Jawa - Bali & 4.484 & 2.570 miliar \\
\hline 5 & Sumatera TOTAL & 491 & 107,05 miliar \\
\hline \multicolumn{2}{|c|}{$\mathbf{5 3 0 4}$} & $\mathbf{3 . 0 7 0 , 8 9}$ miliar \\
\hline
\end{tabular}

Sumber : Bisnis.com http://finansial.bisnis.com

Berbagai jenis perolehaan dana tax amnesty tersebut tidak hanya berpotensi untuk meningkatkan pajak semata bagi penghasilan negara, akan tetapi dana yang telah di laporkan tersebut khususnya dana repatriasi berpotensi besar dalam meningkatkan investasi di Indonesia sebagaimana salah satu tujuan utama di berlakukannya tax amnesty oleh pemerintah yakni peningkatan investasi. Penerapan kebijakan tax amnesty periode pertama oleh pemerintah, diduga memberikan dampak terhadap kinerja keuangan perusahaan, baik yang bersifat negatif maupun positif. Dampak negatif tentu saja akan mengakibatkan penurunan kinerja, sebalikanya dampak positif akan meningkatakan kinerja keuangan perusahaan. Dengan kebijakan tax amnesty tersebut, pemerintah tentu saja megharapakan dampak yang positif terhadap perusahaanperusahaan.

Penelitian untuk membandingakan kinerja keuangan setelah adanya kebijakan dibidang perpajakan telah dilakukan oleh beberapa peneliti, diantaranya: Nugroho (2004); Erlita (2010) dan Sunoto (2011). Penelitian Nugroho (2004) menguji seberapa jauh perbedaan kinerja keuangan perusahaan manufaktur sebelum dan sesudah diterapkannya undang-undang pajak penghasilan tahun 2000. Hasil penelitian menunjukan tidak terdapat perbedaan yang signifikan Return On Investment, Price Earning Ratio, time interest earned dan Debt To Equity Ratio antara sebelum dan setelah tax reform tahun 2000, terdapat perbedaan yang signifikan Return On Equity dan profit margin antara sebelum dan setelah tax reform tahun 2000. Berbeda dengan penelitian yang dilakukan oleh Erlita (2010), dilakukan untuk menganalisis pengaruh reformasi pajak badan tahun 2008 terhadap kinerja keuangan perusahaan perbankan yang terdaftar di BEI. Hasil penelitian menunjukan bahwa terdapat perbedaan yang signifikan antara CAR, NPM dan ROA pada periode sebelum dan sesudah diberlakukannya tarif pajak tahun 2008, tidak ada perbedaan yang signifikan antara RORA pada periode sebelum dan sesudah diberlakukannya tarif pajak tahun 2008.

Selain itu terdapat penelitian yang dilakukan oleh Sunoto (2011) yang melakukan penelitian tentang pengaruh perubahan tarif pajak terhadap kinerja keuangan perusahaan manufaktur yang go publik di Bursa Efek Indonesia periode 2007-2010. Hasil penelitian menunjukan bahwa terdapat peningkatan return on assets dan return on equity perusahaan manufaktur yang go public di BEI pada periode sesudah perubahaan tarif pajak 2008, terdapat penurunan debt to ratio dan price earnings ratio perusahaan manufaktur yang go public di BEI pada periode sesudah perubahaan tarif pajak 2008.

Berdasarkan fenomena maupun penelitian terdahulu yang telah dijelaskan diatas memotivasi peneliti untuk melakukan penelitian dengan objek dan dimensi waktu yang berbeda. Hal ini menjadi landasan akan perlunya kegiatan penelitian mengenai dampak kebijakan tax amnesty terhadap kinerja keuangan perusahaan. Berdasarkan penjelasan yang telah dikemukakan maka perumusan masalah dalam penelitian ini adalah: (1) 
Apakah kinerja keuangan sebelum dan sesudah tax amnesty periode pertama lebih baik bila diukur dengan rasio keuangan berdasarkan angka standar industri pada perusahaan property dan real estate yang terdaftar di BEI? (2) Apakah terjadi perbedaan yang signifikan kinerja keuangan perusahaan property dan real estate yang terdaftar di BEI antara sebelum dan sesudah diberlakukannya tax amnesty periode pertama?. Maka tujuan dari penelitian ini ialah: (1) Untuk mengetahui kinerja keuangan sebelum dan sesudah tax amnesty periode pertama bila diukur dengan rasio keuangan berdasarkan angka standar industri pada perusahaan property dan real estate yang terdaftar di BEI, (2) Untuk mengetahui perbedaan kinerja keuangan perusahaan property dan real estate yang terdaftar di BEI antara sebelum dan sesudah diberlakukannya tax amnesty periode pertama.

\section{KAJIAN TEORI DAN PENELITAN TERDAHULU}

Tax amnesty adalah suatu kesempatan waktu yang terbatas pada kelompok pembayar pajak tertentu untuk membayar sejumlah tertentu dan dalam waktu tertentu berupa pengampunan kewajiban pajak (termasuk bunga dan denda) yang berkaitan dengan masa pajak sebelumnya atau periode tertentu tanpa takut hukuman pidana (Ragimun, 2014). Kementrian Keuangan Direktorat Jendral Pajak, mendefinisikan tax amnesty sebagai penghapusan pajak yang seharusnya terhutang, tidak dikenai sanksi administrasi perpajakan dan sanksi pidana dibidang perpajakan dengan cara mengungkap harta dan membayar uang tebusan. Tujuan diberlakukannya tax amnesty oleh pemerintah diantaranya yakni peningkatan likuiditas domestik, perbaikan nilai tukar, suku bunga yang kompetitif dan peningkatan investasi (Hand Out Materi Amnesty Pajak, Menteri Keuangan Direktorat Jendaral Pajak, 2016). Dengan diberlakukannya tax amnesty ini, diharapkan para pengusaha yang menyimpan dananya di luar negeri akan memindahkan dananya ke Indonesia dan menjadi WP baru yang patuh sehingga dapat meningkatkan pendapatan pajak negara, sehingga tax amnesty menjadi sumber pertumbuhan ekonomi melalui repatriasi asset.

Di Indonesia tax amnesty pernah dilakukan pada tahun 1984. Namun berdasarkan penelitian terhadap implementasi tax amnesty yang pernah dilakukan di Indonesia oleh Ragimun (2014) mengatakan bahwa implementasi tax amnesty yang pernah dilakukan di Indonesia kurang efektif hasilnya karena tidak ada kejelasan tujuan dan aturannya disamping kurangnya sarana dan prasarana yang memadai. Pemerintah Indonesia saat ini sedang melakukan suatu terobosan dalam upaya lebih meningkatkam lagi penerimaan negara dari sektor pajak. Demi terealisasinya hal tersebut maka pemerintah melakukan reformasi dibidang perpajakan dengan mengesahkan undangundang (UU) Nomor 11 Tahun 2016 tentang Pengampunan Pajak pada tanggal 1 Juli tahun 2017 dan mulai berlaku efektif sejak 18 Juli 2016 hingga 31 Maret 2017, dan terbagi dalam tiga periode. Periode pertama dimulai dari 18 Juli hingga 30 September 2016, periode kedua dari 1 Oktober hingga 31 Desember 2016, dan periode ketiga dari 1 Januari hingga 31 Maret 2017. Dengan diterbitkannya undang-undang (UU) Nomor 11 Tahun 2016 tersebut terjadi perubahaan tarif bagi WP maupun WP badan untuk wajib pajak yang bersedia merepatriasi asetnya di luar negeri. Wajib pajak yang mendeklarasikan asetnya di luar negeri tanpa repatriasi akan dikenai tarif $4 \%$ untuk periode Juli-September 2016, 6\% untuk periode Oktober-Desember 2016, dan 10\% untuk periode Januari-Maret 2017. Sedangkan tarif tebusan yang akan diberikan bagi wajib pajak yang mendeklarasikan asetnya di luar negeri dengan repatriasi akan dikenai 
tarif sebesar 2\% untuk Juli-September 2016, 3\% untuk periode Oktober-Desember 2016, dan 5\% untuk periode 1 Januari 2017 sampai 31 Maret 2017.

Reformasi perpajakan yang diterapkan pemerintah melalui kebijakan tax amnesty tidak hanya berdampak terhadap peningkatan kapasitas fiskal semata, tetapi juga terhadap pertumbuhan ekonomi secara makro. Implementasi tax amnesty dengan tarif tebusan yang relatif rendah bagi dana repatriasi yang masuk ke Indonesia tentu saja memberikan dampak terhadap perushaan-perusahaan di Indonesia. Ketika kebijakan tax amnesty (pengampunan pajak) ini diterapkan oleh pemerintah melalui repatriasi aset, maka para pengusaha maupun waraga negara Indonesia yang memiliki harta diluar negeri dengan segera akan melaporkan harta yang dimilikinya dan menarik kembali ke Indonesia. Dengan kembalinya dana-dana tersebut ke dalam negeri menyebabkan sumber pendanaan maupun permodalan investasi di dalam negeri akan semakin tinggi dan perusahaan tidak akan mengalami kesulitan dalam mencari sumber-sumber pendanaan baru untuk melakukan pengembangan perusahaan. Sehingga kemungkinan hal ini dapat mempengaruhi kinerja suatu perusahaan.

Menurut Hanafi (2003: 69) kinerja merupakan suatu usaha formal yang dilaksanakan perusahaan untuk mengevaluasi efisien dan efektivitas dari aktivitas perusahaan yang telah di laksanakan pada periode tertentu. Kinerja keuangan perusahaan merupakan hasil dari banyak keputusan individu yang dibuat secara terus menerus oleh manajemen. Oleh karena itu untuk menilai kinerja keuangan suatu perusahaan, perlu di libatkan anlisa dampak keuangan kumulatif dan ekonomi dari keputusan dan mempertimbangkannya dengan ukuran komparatif (Sucipto, 2003). Kinerja keuangan suatu perusahaan dapat dipengaruhi oleh faktor internal dan faktor eksternal. Salah satu faktor eksternal yang mempengaruhi adalah pajak (Sunoto, 2011). Dampak yang ditimbulkan dari adanya kebijakan perpajakan melalui tax amnesty ini dapat berupa dampak yang bersifat negatif ataupun yang bersifat positif terhadap kinerja keuangan perusahaan yaitu berupa peningkatan atau penurunan terhadap kinerja keuangan. Suatu perusahan tentu saja mempunyai kinerja keuangan yang berbeda dengan perusahaan lainnya. Hal ini disebabkan oleh penggunaan dana dan pengelolaan yang berbeda pula terhadap modal dan aset dari masing-masing perusahaan tersebut. Pengukuran kinerja keuangan perusahaan diperlukan untuk menentukan keberhasilan perusahaan dalam memaksimalkan kekayaan pemegang sahamnya, yaitu perusahaan berhasil memberikan tingkat pengembalian (return) seperti yang diharapkan oleh investor (Shanti,2010). Sumber utama indikator yang dijadikan dasar penilaian ialah laporan keuangan perusahaan yang bersangkutan. Berdasarkan laporan keuangan ini dapat dihitung sejumlah rasio keuangan yang dapat dijadikan sebagai dasar penilaian kinerja keuangan perusahaan.

Rasio keuangan menggambarkan suatu hubungan atau perimbangan (mathematical relationship) antara satu jumlah tertentu dengan jumlah yang lain dan dengan menggunakan alat analisa berupa rasio ini akan dapat menjelaskan atau memberi gambaran kepada penganalisa tentang baik buruknya keadaan atau posisi keuangan suatu perusahaan terutama apabila angka rasio tersebut dibandingkan dengan angka rasio pembanding yang digunakan sebagai standar (Munawir, 2004:64). Analisis rasio keuangan merupakan instrumen analisa perusahaan yang ditujukan untuk menunjukan perubahaan dalam kondisi keuangan perusahaan yang bersangkutan. Dengan anlisa rasio keuangan ini dapat diketahui kekuatan dan kelemahaan perusahaan di bidang keuangan (Husnan, 2003:44). 
Untuk menganalisis laporan keuangan beberapa rasio dapat digunakan untuk mengevaluasi yakni liquiditas, rentabilitas, solvabilitas dan ativitas perusahaan (Sunoto, 2011). Rasio tersebut dapat memberikan petunjuk untuk kondisi-kondisi mendasar yang mungkin tidak tampak jelas dari masing-masing komponen laporan keuangan.

\section{a. Rasio Likuiditas}

Menurut Munawir (2014:239), menyatakan bahwa rasio likuiditas, yaitu rasio untuk mengetahui kemampuan perusahaan dalam membiayai operasi dan memenuhi kewajiban finansial pada saat di tagih. Dalam penelitian ini menggunakan rasio lancar (current ratio). Alasan peneliti menggunakan rasio lancar untuk mengukur likuditas perusahaan karena pada pada rasio lancar persediaan termasuk dalam aset lancar berbeda dengan rasio cepat yang justru mengurangkan persediaan dari aset lancarnya dimana persediaan dapat di jaminkan untuk menjamin utang perusahaan. Kesehatan suatu perusahaan yang dicerminkan dengan tingginya rasio likuiditas yang diukur dengan rasio lancar akan berhubungan dengan kelengkapan tingkat pengungkapan. Secara finansial perusahaan yang kuat lebih banyak mengungkapkan informasi daripada perusahaan yang lemah (Shanti:2010).

\section{b. Rasio Leverage}

Rasio Leverage, yaitu rasio untuk mengukur sampai seberapa jauh aktiva perusahaan dibiayai dari hutang. Dengan mengetahui leverage rasio akan dapat dinilai tentang: (a) posisi perusahaan terhadap seluruh kewajibannya kepada pihak lain (b) kemampuan perusahaan dalam memenuhi kewajiban yang bersifat tetap (c) keseimbangan antara nilai aktiva tetap dengan modal. Dalam penelitian ini peneliti menggunakan rasio hutang terhadap modal sendiri (DER) karena rasio ini menunjukan berapa bagian dari setiap rupiah modal sendiri yang dijadikan jaminan untuk utang Munawir (2014:239). Bagi perusahaan makin besar rasio ini akan semakin menguntungkan, tetapi bagi pihak bank semakin besar rasio ini berarti akan semakin besar risiko yang ditanggung atas kegagalan perusahaan yang mungkin terjadi.

\section{c. Rasio Aktivitas}

Munawir (2014:240) menyatakan bahwaa rasio aktivitas, yaitu rasio untuk menilai kemampuan perusahaan dalam melaksanakan aktivitas sehari-hari atau kemampuan perusahaan dalam penjualan, penagihan piutang maupun pemanfaatan aktiva yang dimiliki. Dalam penelitian ini peneliti menggunakan rasio antara penjualan dengan total aktiva (TATO). Alasan peneliti menggunakan rasio ini karena TATO memperhitungkan seluruh aktiva (harta) yang dimiliki perusahaan baik aset lancar maupaun aset tetapnya dalam menghasilkan penjulan bagi perusahaan. Semakin tinggi TATO maka akan semakin baik bagi perusahaan karena menunjukan bahwa semakin besar kemampuan perusahaan dalam menghasilkan penjulan dari penggunaan aset.

\section{d. Rasio Profitabilitas}

Hanafi \& Halim (2016 : 81) menyatakan bahwa rasio profitabilitas, yaitu rasio yang mengukur kemampuan perusahaan menghasilkan keuntungan (profitabilitas) pada tingkat penjulan, aset dan modal saham tertentu. Dalam penelitian ini peneliti menggunakan rasio laba bersih terhadap modal saham (ROE). Alasan peneliti menggunakan ROE karena rasio ini mengukur laba dari sudut pandang pemegang saham maupun investor. Sehingga dengan menggunakan rasio ini investor akan dapat mengetahui seberapa besar modal saham yang ditanamkannya dapat menghasilkan keuntungan bagi perusahaan dan juga pemegang saham. 
Penelitian untuk membandingakan kinerja keuangan setelah adanya kebijakan dibidang perpajakan telah dilakukan oleh beberapa peneliti, diantaranya: Nugroho (2004); Erlita (2010) dan Sunoto (2011). Penelitian Nugroho (2004) menguji seberapa jauh perbedaan kinerja keuangan perusahaan manufaktur sebelum dan sesudah diterapkannya undang-undang pajak penghasilan tahun 2000. Hasil penelitian menunjukan tidak terdapat perbedaan yang signifikan Return On Investment, Price Earning Ratio, time interest earned dan Debt To Equity Ratio antara sebelum dan setelah tax reform tahun 2000, terdapat perbedaan yang signifikan Return On Equity dan profit margin antara sebelum dan setelah tax reform tahun 2000. Berbeda dengan penelitian yang dilakukan oleh Erlita (2010), dilakukan untuk menganalisis pengaruh reformasi pajak badan tahun 2008 terhadap kinerja keuangan perusahaan perbankan yang terdaftar di BEI. Hasil penelitian menunjukan bahwa terdapat perbedaan yang signifikan antara CAR, NPM dan ROA pada periode sebelum dan sesudah diberlakukannya tarif pajak tahun 2008, tidak ada perbedaan yang signifikan antara RORA pada periode sebelum dan sesudah diberlakukannya tarif pajak tahun 2008. Selain itu terdapat penelitian yang dilakukan oleh Sunoto (2011) yang melakukan penelitian tentang pengaruh perubahan tarif pajak terhadap kinerja keuangan perusahaan manufaktur yang go publik di Bursa Efek Indonesia periode 2007-2010. Hasil penelitian menunjukan bahwa terdapat peningkatan return on assets dan return on equity perusahaan manufaktur yang go public di BEI pada periode sesudah perubahaan tarif pajak 2008, terdapat penurunan debt to ratio dan price earnings ratio perusahaan manufaktur yang go public di BEI pada periode sesudah perubahaan tarif pajak 2008.

Berdasarkan tinjauan pustaka, baik teoritis maupun hasil penelitian terdahulu, peneliti menggambarkan kerangka konseptual perbandingan kinerja keuangan perusahaan sebelum dan sesudah tax amnesty periode pertama pada perusahaan property dan real estate yang terdaftar di BEI, sebagai berikut:

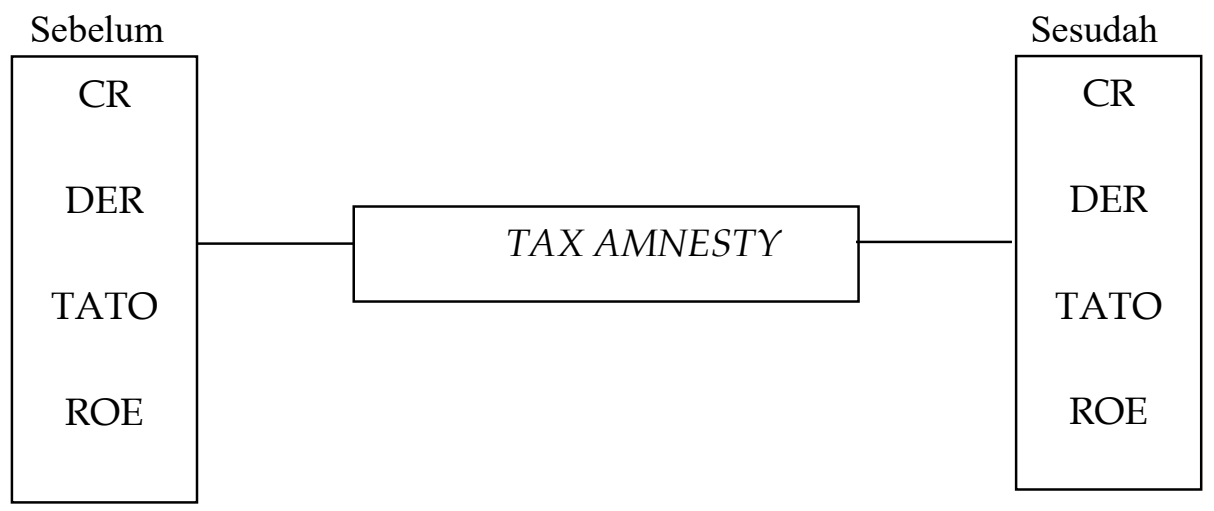

Gambar 1. Kerangka Konseptual Penelitian

Berdasarkan penelitian terdahulu dan juga kerangka konseptual diatas, penelitian-penelitian terdahulu yang menyatakan bahwa penerapan kebijakan dibidang perpajakan memberikan dampak yang berbeda-beda terhadap kinerja keuangan perusahaan, maka dirumuskan hipotesis alternatif konsep (Ha) sebagai berikut:

Untuk menguji apakah masing-masing rasio keuangan yang digunakan untuk mengukur kinerja keuangan perusahaan sebelum tax amnesty berbeda secara signifikan 
dengan rasio keuangan perusahaan sesudah tax amnesty, maka dirumuskan hipotesis alternatif operasional (H1-H4), sebagai berikut:

H1 : Terdapat perbedaan yang signifikan Current Ratio perusahaan property dan real estate yang terdaftar di BEI sebelum dan sesudah diberlakukannya tax amnesty periode pertama.

H2 : Terdapat perbedaan yang signifikan Debt to Equity Ratio perusahaan property dan real estate yang terdaftar di BEI periode sebelum dan sesudah diberlakukannya tax amnesty periode pertama.

H3 : Terdapat perbedaan yang signifikan Total Asset Turn Over perusahaan property dan real estate yang terdaftar di BEI periode sebelum dan sesudah diberlakukannya tax amnesty periode pertama.

H4 : Terdapat perbedaan yang signifikan Return On Equity perusahaan property dan real estate yang terdaftar di BEI periode sebelum dan sesudah diberlakukannya tax amnesty periode pertama.

\section{METODE PENELITIAN}

Jenis penelitian yang digunakan yakni penelitian komparatif dengan pendekatan kuantitatif. Ferdinand (2006:5) mendefinisikan bahwa penelitian komparatif adalah penelitian yang dilakukan tidak untuk secara langsung menjelaskan hubungan sebab akibat, tetapi melakukan berbagi perbandingan antara beberapa situasi yang terjadi. Menurut Sugiyono (2008:13) pendekatan kuantitatif lebih menitikberatkan pada pembuktian hipotesis (hypotesis testing). Penelitian ini dilakukan pada perusahaan property dan real estate yang terdaftar di Bursa Efek Indonesia melalui fasilitas internet. Metode pengumpulan data yang digunakan adalah sample survey. Populasi penelitian adalah semua perusahaan property dan real estate yang terdaftar di Bursa Efek Indonesia hingga tahun 2016 yaitu sejumlah 49 perusahaan. Teknik pengambilan sampel dilakukan melalui teknik purposive sampling dan diperoleh sebanyak 43 perusahaan sampel. Kriteria sampel adalah (1) Perusahaan property dan real estat yang terdaftar di Bursa Efek Indonesia sampai tahun 2016; (2) Tersedia laporan keuangan selama periode triwulan II dan triwulan III tahun 2016; (3) Perusahaan tidak mengalami kerugian selama periode penelitian; dan (4) Tersedia catatan atas laporan keuangan yang mendukung variabel penelitian.

Teknik pengumpulan data adalah dokumentasi dan jenis data yang digunakan ialah data kuantitatif yang di peroleh peneliti secara tidak langsung melalui media perantara atau yang diperoleh dan dicatat oleh pihak lain yakni berupa laporan keuangan triwulan II dan triwulan III yang di publikasikan oleh Bursa Efek Indonesia melalui website www.idx.co.id dan www.sahamok.com. Prosesdur analisis yang digunakan dalam penelitian ini adalah sebagai berikut:

1. Menghitung masing-masing rasio keuangan setiap perusahaan

2. Menilai rasio keuangan perusahaan sampel berdasarkan angka rata-rata industri untuk menilai kinerja keuangan perusahaan.

3. Menentukan normalitas data melalui uji nomalitas Kolmogrov Smirnov.

4. Melakukan pengujian hipotesis untuk menentukan perbedaan keuangan perusahaan property dan real estate antara sebelum dan sesudah diberlakukannya tax amnesty dengan uji t paired sample t-test (uji t berpasangan) dengan level of signifikansi 
$(\alpha)=0.05$. Rumus t-test yang di gunakan untuk menguji hipotesis komparatif, sebagai berikut (Sugiyono : 1999)

$$
t=\frac{\mathrm{x} 1-\mathrm{x} 2}{\sqrt{\frac{\mathrm{s}_{12}}{\mathrm{n}_{1}}}+\frac{\mathrm{s}_{2} 2}{\mathrm{n}_{2}}-2 \mathrm{r}\left(\frac{\mathrm{s}_{1}}{\sqrt{\mathrm{n}_{1}}}\right)\left(\frac{\mathrm{s}_{2}}{\sqrt{\mathrm{n}_{2}}}\right)}
$$

Keterangan rumus:

$\overline{\mathrm{x}} 1 \quad=$ Rata-rata sampel 1

$\overline{\mathrm{x}} 2=$ Rata-rata sampel 2

s1 = Simpangan baku sampel 1

s2 = Simpangan baku sampel 2

$\mathrm{s}_{12}=$ Varians Sampel 1

$\mathrm{S}_{2}{ }^{2}=$ Varians Sampel 2

$\mathrm{R} \quad=$ Korelasi antar sampel

Keriteria Pengujian:

a. Jika sig $\mathrm{t}>0,05$ maka Ho diterima, artinya secara parsial tidak ada perbedaan yang signifikan antara kinerja keuangan sebelum dan sesudah diterapkannya tax amnesty (Santoso, 2009:362).

b. Jika sig $\mathrm{t}<0,05$ maka Ho ditolak, artinya secara parsial terdapat perbedaan yang signifikan antara kinerja keuangan sebelum dan sesudah diterapkannya tax amnesty (Santoso, 2009:362).

5. Menginterpretasikan hasil pengujian hipoteis

6. Menarik kesimpulan tentang ada tidaknya perbedaan kinerja keuangan perusahaan property dan real estate antara sebelum dan sesudah diberlakuknnya tax amnesy dari hasil uji beda yang dilakukan melalui uji paired sample t-test.

\section{HASIL DAN PEMBAHASAN}

Objek penelitian ini adalah perusahaan property dan real estate yang terdaftar di Bursa Efek Indonesia. Analisis statistik deskriptif digunakan untuk mengetahui deskripsi suatu data yang dilihat dari nilai maksimum, nilai minimum, nilai rata-rata (mean), dan nilai standar deviasi. Berdasarkan analisis statistik deskriptif diperoleh gambaran sampel pada Tabel 4.

Tabel 4. Statistik Deskriptif

\begin{tabular}{|l|r|r|r|r|r|}
\hline & \multicolumn{1}{c|}{ N } & \multicolumn{1}{c|}{ Minimum } & Maximum & \multicolumn{1}{c|}{ Mean } & \multicolumn{1}{c|}{ Std. Deviation } \\
\hline CR_sebelum & 43 & 0.260 & 18.748 & 2.5385 & 2.9943 \\
\hline DER_sebelum & 43 & 0.008 & 1.969 & 0.7519 & 0.4999 \\
\hline TATO_sebelum & 43 & 0.001 & 1.000 & 0.1218 & 0.1537 \\
\hline ROE_sebelum & 43 & 0.003 & 5.740 & 0.4914 & 1.0494 \\
\hline CR_sesudah & 43 & 0.052 & 23.088 & 3.4081 & 4.4116 \\
\hline DER_sesudah & 43 & 0.043 & 1.894 & 0.7314 & 0.4992 \\
\hline TATO_sesudah & 43 & 0.001 & 0.016 & 0.1432 & 0.0890 \\
\hline ROE_sesudah & 43 & 0.003 & 9.508 & 0.7795 & 1.8450 \\
\hline Valid N (listwise) & 43 & & & & \\
\hline
\end{tabular}


Tabel 4. memberikan gambaran mengenai variabel yang digunakan dalam penelitian, jumlah sampel, nilai minimum, nilai maksimum, nilai rata-rata (mean), dan standar deviasi masing-masing variabel. Selanjurnya rasio keuangan tersebut dinilai baik ataukah tidak berdasarkan angka rata-rata industri. Tabel 4 . Berikut memberikan gambaran tentang penilaian rasio keuangan berdasarkan standar industri:

Tabel 5. Penilaian rasio keuangan berdasarkan rata-rata industri

\begin{tabular}{|l|l|c|c|c|c|}
\hline \multirow{2}{*}{ No } & \multirow{2}{*}{ Jenis Rasio Keuangan } & \multicolumn{2}{|c|}{ KebijakaTax Amnesty } & \multicolumn{2}{c|}{ Rata-Rata Industri } \\
\cline { 3 - 6 } & & Sebelum & Sesudah & Sebelum & Sesudah \\
\hline 1 & Current Ratio & $253,83 \%$ & $340,81 \%$ & $316,24 \%$ & $397,98 \%$ \\
\hline 2 & Debt to Equity Ratio & $75,19 \%$ & $73,14 \%$ & $73,17 \%$ & $71,58 \%$ \\
\hline 3 & Total Assets Turn Over & $0,12 \mathrm{kali}$ & $0,14 \mathrm{kali}$ & $0,12 \mathrm{kali}$ & $0,14 \mathrm{kali}$ \\
\hline 4 & Retun On Equity & $49,14 \%$ & $77,95 \%$ & $39,81 \%$ & $65,68 \%$ \\
\hline
\end{tabular}

Sumber : Data keuangan yang telah diolah

Dari Tabel 5. diatas yang merupakan penilaian rasio keuangan berdasarkan rata-rata industri pada perusahaan property dan real estate dapat kita ketahui bahwa $\mathrm{CR}$ perusahaan antara sebelum dan sesudah tax amnesty mengalami peningkatan, namun memiliki nilai dibawah angka rata-rata industri yang berlaku. Sehingga CR perusahaan sebelum dan sesudah tax amnesty periode pertama tidak lebih baik bila dinilai dari standar industri. Sedangkan untuk DER, perusahaan memiliki DER diatas angka ratarata industri baik sebelum maupun sesudah tax amnesty periode pertama. Nilai ini menggambarkan bahwa rasio utang perusahaan telah melewati batas yang diisyaratkan oleh industri sehingga rasio DER sebelum maupun sesudah tax amnesty tidak lebih baik bila dinilai berdasarkan angka rata-rata industri yang berlaku.

Selanjutnya untuk TATO antara sebelum dan sesudah tax amnesty periode pertama perusahaan memiliki TATO yang semakin meningkat dan memiliki nilai yang sama dengan angka rata-rata industri. Sehingga nilai ini menunjukan bahwa TATO perusahaan baik karena telah mampu mencapai angka standar industri yang berlaku. Sedangkan untuk ROE antara sebelum dan sesudah tax amnesty periode pertama mengalami peningkatan dan memiliki nilai diatas angka rata-rata industri yang berlaku. Sehingga nilai ini menunjukan bahwa ROE perusahaan baik karena telah mampu mencapai mencapai angka standar industri yang berlaku.

Oleh karena itu, dapat disimpulkan bahwa dari empat rasio keuangan yang digunakan sebagai variabel penelitian yang dinilai berdasarkan angka rata-rata industri sebelum dan sesudah tax amnesty periode pertama terdapat dua rasio yakni CR dan DER yang tidak mencapai standar industri yang berlaku sehingga memiliki rasio yang kurang baik. Sedangkan, dua rasio lainnya, yakni TATO dan ROE telah mancapai standar industri yang berlaku (diisyaratkan) sehingga kedua rasio ini dapat dikatakan lebih baik dari angka rata-rata industri.

Uji Normalitas bertujuan apakah suatu data mempunyai distribusi normal atau tidak. Uji normalitas dilakukan dengan uji Kolmogrov Smirnov. Bila tingkat signifikansi $>$ dari $5 \%$ data terdistribusi normal. 
Tabel 6. Normalitas Data One Sample Kolmogrov Smirnov Test

\begin{tabular}{|c|c|c|c|c|c|c|c|c|c|}
\hline & & $\begin{array}{c}\mathrm{CR} \\
\mathrm{sblm}\end{array}$ & $\begin{array}{l}\text { DER } \\
\text { Sblm }\end{array}$ & $\begin{array}{l}\text { TATO } \\
\text { Sblm }\end{array}$ & $\begin{array}{l}\text { ROE } \\
\text { sblm }\end{array}$ & $\begin{array}{c}\text { CR } \\
\text { sudah } \\
\end{array}$ & $\begin{array}{c}\text { DER } \\
\text { sudah }\end{array}$ & $\begin{array}{l}\text { TATO } \\
\text { sudah }\end{array}$ & $\begin{array}{l}\text { ROE } \\
\text { Sudah }\end{array}$ \\
\hline $\mathrm{N}$ & & 43 & 43 & 43 & 43 & 43 & 43 & 43 & 43 \\
\hline \multirow{2}{*}{$\begin{array}{l}\text { Normal } \\
\text { Parameters }\end{array}$} & Mean & 5.1730 & 3.9641 & 2.0921 & 2.6282 & 5.3847 & 4.0979 & 2.8445 & 2.8702 \\
\hline & \begin{tabular}{|l|} 
Std. \\
Deviation
\end{tabular} & .81738 & 1.07397 & .94251 & 1.65595 & .86085 & 1.14745 & 1.83690 & 1.78896 \\
\hline \multirow{3}{*}{$\begin{array}{l}\text { Most Extreme } \\
\text { Differences }\end{array}$} & Absolute & .064 & .171 & .206 & .091 & .121 & .137 & .102 & .089 \\
\hline & Positive & .064 & .118 & .142 & .083 & .121 & .136 & .102 & .085 \\
\hline & Negative & -.058 & -.171 & -.206 & -.091 & -.075 & -.137 & -.061 & -.089 \\
\hline \multicolumn{2}{|c|}{ Kolmogorov-Smirnov Z } & .418 & 1.120 & 1.349 & .597 & .795 & .896 & 1.168 & .669 \\
\hline \multicolumn{2}{|c|}{ Asymp. Sig. (2-tailed) } & .995 & .162 & .052 & .868 & .553 & .398 & .131 & .762 \\
\hline
\end{tabular}

Hasil output spss menunjukan bahwa hasilnya diatas tingkat kepercayaan 5\% sehingga layak dipakai karena memenuhui asumsi normalitas.Berdasarkan pada hasil pengujian hipotesis dengan menggunakan uji beda dua rata-rata (paired sample t-test) mengenai perbedaan pada veriabel-variabel penelitian yakni CR, DER, TATO dan ROE pada perusahaan property dan real estate yang terdaftar di BEI sebelum dan sesudah diberlakukannya tax amnesty periode pertama tahun 2016 menghasilkan pengujian hipotesis sebagai berikut:

\section{Analisis Hipotesis 1}

Pengujian hipotesis pertama menguji apakah terdapat perbedaan Current Ratio antara sebelum dan sesudah diberlakukannya tax amnesty pada perusahaan property dan real estate yang terdafatar di BEI. Hasil pengujian dapat dilihat pada tabel berikut ini:

Tabel 7. Hasil Pengujian Paired Sample t-test CR

\begin{tabular}{|c|c|c|c|c|c|c|c|c|c|}
\hline & & \multicolumn{5}{|c|}{ Paired Differences } & \multirow[b]{3}{*}{$\mathrm{T}$} & \multirow[b]{3}{*}{ Df } & \multirow{3}{*}{$\begin{array}{l}\text { Sig. }(2- \\
\text { tailed })\end{array}$} \\
\hline & & \multirow[b]{2}{*}{ Mean } & \multirow{2}{*}{$\begin{array}{c}\text { Std. } \\
\text { Deviation }\end{array}$} & \multirow{2}{*}{$\begin{array}{c}\text { Std. Error } \\
\text { Mean }\end{array}$} & \multicolumn{2}{|c|}{$\begin{array}{c}95 \% \text { Confidence Interval } \\
\text { of the Difference }\end{array}$} & & & \\
\hline & & & & & Lower & Upper & & & \\
\hline $\begin{array}{l}\text { Pair } \\
1\end{array}$ & $\begin{array}{l}\text { CR_sebelum } \\
\text { CR_sesudah }\end{array}$ & -.21171 & .64860 & .09891 & -.41132 & -.01210 & -2.140 & 42 & .038 \\
\hline
\end{tabular}

Berdasarkan Tabel 7. diatas yang merupakan hasil pengolahan data menggunakan uji beda dua rata-rata (paired sample t-test) dengan signifikansi 0,05 , menghasilkan hasil analisis statistik yang menunjukan bahwa sebelum dan sesudah diberlakukannya tax amnesty periode pertama tahun 2016 nilai $\mathrm{t}$ hitung $=2,140>\mathrm{t}$ tabel $=2,018$ dengan signifikansi sebesar 0,038 dibawah nilai $\alpha$ yaitu sebesar 0,05 sehingga hipotesis pertama (H1) diterima. Artinya bahwa terjadi perbedaan yang signifikan antara CR sebelum dan sesudah diberlakukannya tax amnesty periode pertama. Perbedaan terhadap CR tersebut mengindikasikan adanya peningkatan investasi berupa aktiva lancar dari pemanfaatan aliran dana repatriasi aset yang yang masuk ke Indonesia dari penerapan tax amnesty dengan tetap mengendalikan atau menekan utang lancar yang dimiliki oleh perusahaan sehingga hal ini berdampak terhadap rasio lancar yang dimiliki oleh perusahaan. 


\section{Analisis Hipotesis 2}

Pengujian hipotesis kedua menguji apakah terdapat perbedaan Debt to Equity Ratio antara sebelum dan sesudah diberlakukannya tax amnesty pada perusahaan property dan real estate yang terdafatar di BEI. Hasil pengujian dapat dilihat pada tabel berikut ini:

Tabel 8. Hasil Pengujian Paired Sample t-test DER

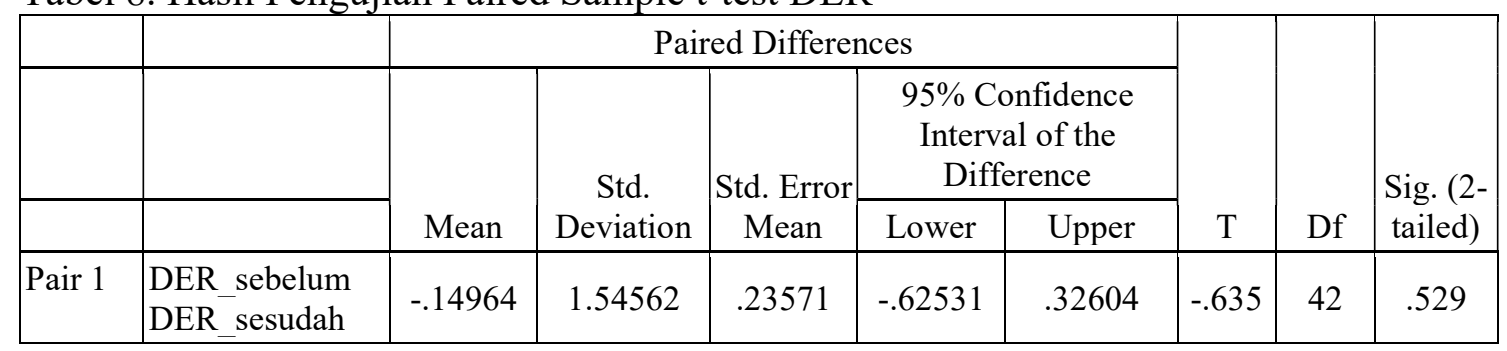

Berdasarkan Tabel 8. di atas yang merupakan hasil pengolahan data menggunakan uji beda dua rata-rata (paired sample t-test) dengan signifikansi 0,05 , menghasilkan hasil analisis statistik yang menunjukan bahwa sebelum dan sesudah diberlakukannya tax amnesty periode pertama tahun 2016 nilai $\mathrm{t}$ hitung $=0,635<\mathrm{t}$ tabel $=2,018$ dengan signifikansi sebesar 0,529 diatas nilai $\alpha$ yaitu sebesar 0,05 sehingga hipotesis kedua $(\mathrm{H} 2)$ ditolak. Artinya bahwa tidak terjadi perbedaan yang signifikan antara DER sebelum dan sesudah diberlakukannya tax amnesty periode pertama.

Hasil tersebut mendukung penelitian yang dilakukan oleh Nugroho (2004) yang menguji apakah terdapat perbedaan kinerja keuangan perusahaan manufaktur sebelum dan sesudah diterapkannya undang-undang pajak penghasilan tahun 2000. Kinerja perusahaan di ukur dengan menggunakan rasio Return On Investment, Return On Equity, Profit Margin Price Earning Ratio dan menggunakan Laverage Ratio yang diukur dengan menggunakan rasio Time Interest Earned dan Debt To Equity Ratio. Salah satu hasil penelitian tersebut menunjukan bahwa tidak terdapat perbedaan yang signifikan Debt To Equity Ratio antara sebelum dan setelah tax reform tahun 2000. Hal ini mengindikasikan bahwa penerapan tax amnesty oleh pemerintah tidak menyebabkan perbedaan yang berarti terhadap DER perusahaan karena pemanfaatan sumber pendanaan utang masih relatif tetap antara sebelum maupun sesudah tax amnesty yang ditunjukan dengan tidak terjadinya perbedaan yang signifikan jumlah utang maupun modal sendiri sebelum dan sesudah diberlakukannya tax amnesty periode pertama.

\section{Analisis Hipotesis 3}

Pengujian hipotesis ketiga menguji apakah terdapat perbedaan Total Asset Turn Over antara sebelum dan sesudah diberlakukannya tax amnesty pada perusahaan property dan real estate yang terdafatar di BEI. Hasil pengujian dapat dilihat pada tabel berikut ini:

Tabel 9. Hasil Pengujian Paired Sample t-test TATO

\begin{tabular}{|c|c|c|c|c|c|c|c|c|c|}
\hline & & \multicolumn{5}{|c|}{ Paired Differences } & \multirow[b]{3}{*}{$\mathrm{T}$} & \multirow[b]{3}{*}{ Df } & \multirow{3}{*}{$\begin{array}{l}\text { Sig. (2- } \\
\text { tailed) }\end{array}$} \\
\hline & & \multirow[b]{2}{*}{ Mean } & \multirow{2}{*}{$\begin{array}{c}\text { Std. } \\
\text { Deviation }\end{array}$} & \multirow{2}{*}{$\begin{array}{l}\text { Std. Error } \\
\text { Mean }\end{array}$} & \multicolumn{2}{|c|}{$\begin{array}{l}\text { 95\% Confidence } \\
\text { Interval of the } \\
\text { Difference }\end{array}$} & & & \\
\hline & & & & & Lower & Upper & & & \\
\hline Pair 1 & $\begin{array}{l}\text { TATO_sbelum } \\
\text { TATO_sudah }\end{array}$ & -.38121 & .70984 & .10825 & -.59966 & -.16275 & -3.522 & 42 & .001 \\
\hline
\end{tabular}

14 | Analisis Perbandingan Kinerja Keuangan Sebelum dan Sesudah Diberlakukannya Tax Amnesty .... 
Berdasarkan Tabel 9. di atas yang merupakan hasil pengolahan data menggunakan uji beda dua rata-rata (paired sample t-test) dengan signifikansi 0,05 , menghasilkan hasil analisis statistik yang menunjukan bahwa sebelum dan sesudah diberlakukannya tax amnesty periode pertama tahun 2016 nilai thitung $=3,522>\mathrm{t}$ tabel $=2,018$ dengan signifikansi sebesar 0,001 dibawah nilai $\alpha$ yaitu sebesar 0,05 sehingga hipotesis ketiga $(\mathrm{H} 3)$ diterima. Artinya bahwa terjadi perbedaan yang signifikan antara TATO sebelum dan sesudah diberlakukannya tax amnesty periode pertama. Perbedaan tersebut mengindikasikan bahwa penerapan tax amnesty oleh pemerintah memberikan dampak terhadap rasio aktivitas perusahaan yang diukur dengan TATO yang ditunjukan dengan terjadinya peningkatan terhadap aktivitas perusahaan sesudah tax amnesty untuk meningkatkan perputaran total aktiva dalam menghasilkan penjualan bagi perusahaan.

\section{Analisis Hipotesis 4}

Pengujian hipotesis keempat menguji apakah terdapat perbedaan Return On Equity antara sebelum dan sesudah diberlakukannya tax amnesty pada perusahaan property dan real estate yang terdafatar di BEI. Hasil pengujian dapat dilihat pada tabel berikut ini:

Tabel 10. Hasil Pengujian Paired Sample t- test ROE

\begin{tabular}{|c|c|c|c|c|c|c|c|c|c|}
\hline & & \multicolumn{5}{|c|}{ Paired Differences } & \multirow[b]{3}{*}{$\mathrm{T}$} & \multirow[b]{3}{*}{ Df } & \multirow{3}{*}{$\begin{array}{l}\text { Sig. } \\
(2- \\
\text { tailed) }\end{array}$} \\
\hline & & \multirow[b]{2}{*}{ Mean } & \multirow{2}{*}{$\begin{array}{c}\text { Std. } \\
\text { Deviatio } \\
n\end{array}$} & \multirow{2}{*}{$\begin{array}{l}\text { Std. } \\
\text { Error } \\
\text { Mean }\end{array}$} & \multicolumn{2}{|c|}{$\begin{array}{l}95 \% \text { Confidence } \\
\text { Interval of the } \\
\text { Difference }\end{array}$} & & & \\
\hline & & & & & Lower & Upper & & & \\
\hline $\begin{array}{l}\text { Pair } \\
1\end{array}$ & $\begin{array}{l}\text { ROE_sbelum } \\
\text { ROE_sudah }\end{array}$ & $.21630^{-}$ & .56071 & .08551 & -.38886 & -.04374 & -2.530 & 42 & .015 \\
\hline
\end{tabular}

Berdasarkan Tabel 10. diatas yang merupakan hasil pengolahan data menggunakan uji beda dua rata-rata (paired sample t-test) dengan signifikansi 0,05 , menghasilkan hasil analisis statistik yang menunjukan bahwa sebelum dan sesudah diberlakukannya tax amnesty periode pertama tahun 2016 nilai $\mathrm{t}$ hitung $=2,530>\mathrm{t}$ tabel $=2,018$ dengan signifikansi sebesar 0,015 dibawah nilai $\alpha$ yaitu sebesar 0,05 sehingga hipotesis keempat $(\mathrm{H} 4)$ diterima. Artinya bahwa terjadi perbedaan yang signifikan antara ROE sebelum dan sesudah diberlakukannya tax amnesty periode pertama.

Hasil tersebut mendukung penelitian yang dilakukan oleh Nugroho (2004) yang menguji seberapa jauh perbedaan kinerja keuangan perusahaan manufaktur sebelum dan sesudah diterapkannya undang-undang pajak penghasilan tahun 2000. Salah satu hasilnya penelitiannnya yaitu terdapat perbedaan yang signifikan return on equity antara sebelum dan sesudah tax reform tahun 2000. Hasil tersebut juga mendukung penelitian oleh Sunoto (2011) yang meneliti tentang pengaruh perubahan tarif pajak terhadap kinerja keuangan perusahaan manufaktur yang go publik di Bursa Efek Indonesia periode 2007-2010. Kinerja keuangan perusahaan diukur dengan menggunakan rasio return on assets, return on equity, debt to equity ratio, dan price earnings ratio. Salah satu hasil penelitian tersebut menunjukan bahwa terdapat peningkatan return on equity perusahaan manufaktur yang go public di BEI pada periode sesudah perubahaan tarif pajak 2008.

Hasil ini juga mengindikasikan bahwa penerapan tax amnesty periode pertama oleh pemerintah menyebabkan terjadinya perbedaan terhadap ROE perusahaan karena modal saham yang diinvestasikan perusahaan mampu menghasilkan laba bersih yang terus meningkat pada perusahaan sesudah adanya tax amnesty. Perbedaan terhadap laba 
bersih perusahaan yang terus meningkat tersebut berbanding lurus dengan penjualan perusahaan yang juga semakin meningkat setelah diberlakukan tax amnesty. Sehingga hal ini mengakibatakan rasio profitabilitas perusahaan property dan real estate yang diukur dengan ROE juga berbeda sifnifikan antara sebelum dan sesudah diberlakukannya tax amnesty periode pertama.

\section{KESIMPULAN}

Penelitian ini bertujuan untuk (1) mengetahui kinerja keuangan sebelum dan sesudah tax amnesty periode pertama bila diukur dengan rasio keuangan berdasarkan angka standar industri pada perusahaan property dan real estate yang terdaftar di BEI, (2) menganalisis perbedaan kinerja keuangan sebelum dan sesudah diberlakukannya tax amnesty periode pertama pada perusahaan property dan real estate yang terdaftar di BEI. Berdasarkan hasil penelitian data dan uji statistik yang telah dilakukan, maka dapat diperoleh kesimpulan penelitian, sebagai berikut:

1. Terdapat perbedaan yang signifikan Current Ratio antara sebelum dan sesudah diberlakukannya tax amnesty periode pertama pada perusahaan property dan real estate yang terdaftar di BEI karena adanya peningkatan investasi berupa aktiva lancar dari aliran dana repatriasi aset dengan tetap mengendalikan atau menekan utang lancar yang dimiliki perusahaan.

2. Tidak terdapat perbedaan yang signifikan Debt To Equity Ratio antara sebelum dan sesudah diberlakukannya tax amnesty periode pertama pada perusahaan property dan real estate yang terdaftar di BEI karena pemanfaatan sumber pendanaan utang masih relatif tetap antara sebelum maupun sesudah tax amnesty.

3. Terdapat perbedaan yang signifikan Total Assets Turn Over antara sebelum dan sesudah diberlakukannya tax amnesty periode pertama pada perusahaan property dan real estate yang terdaftar di BEI karena adanya peningkatan aktivitas perusahaan sesudah adanya tax amnesty untuk meningkatkan perputaran total aktiva dalam menghasilkan penjualan perusahaan.

4. Terdapat perbedaan yang signifikan Return On Equity antara sebelum dan sesudah diberlakukannya tax amnesty periode pertama pada perusahaan property dan real estate yang terdaftar di BEI dikarenakan modal saham yang diinvestasikan perusahaan mampu menghasilkan laba bersih yang terus meningkat pada perusahaan sesudah adanya tax amnesty.

\section{SARAN}

Berdasarkan kesimpulan hasil penelitian, maka ada beberapa saran yang diajukan oleh penulis, sebagai berikut:

1. Untuk mempertahankan rasio keuangan perusahaan yang tergolong sehat tersebut, yakni TATO dan ROE maka manajemen perusahan perlu menyeimbangakan antara total aktiva dan juga modal sendiri perusahaan sehingga dapat menghasilkan penjualan dan juga laba bersih yang semakin tinggi. Sedangakan untuk memperbaiki CR dan DER yang masih kurang baik, perusahaan perlu mengendalikan utang lancar maupun utang jangka panjangnya dengan mengusahakan peningkatan pada aktiva lancar dan modal sendiri agar persentase rasio lancar dan juga rasio utang perusahaan dapat terus meningkat.

2. Perusahaan hendaknya dapat meningkatkan posisi likuiditas perusahaan setelah tax amnesty dengan tetap berusaha untuk meningkatkan aktiva lancar perusahaan 
melalui pemanfaatan repatriasi aset agar dapat menjamin seluruh utang lancar yang dimiliki perusahaan dengan baik serta tetap menjaga agar utang lancar perusahaan dapat di tekan atau dikurangi.

3. Rasio solvabilitas perusahan sebelum dan sesudah tax amnesty tidaklah berbeda, akan tetapi untuk memepertahankan maupun menstabilkan rasio tersbut, perusahaan hendaknya tetap menjaga agar jumlah utang yang dimiliki perusahaan tidak terlalu besar dan tetap mempertahankan agar modal sendiri yang dimiliki perusahaan tetap meningkat sehingga dapat menjamin utang yang dimiliki perusahaan.

4. Perusahaan perlu untuk meningkatakan dan menjaga kesetabilan posisi profitabilitas perusahaan dari sebelum hingga sesudah adanya tax amnesty dengan cara meningkatkan penjualan perusahaan, meningkatakan efisiensi dan efektifitas penggunaan modal saham yang diinvestasikan serta menekan biaya operasional agar pendapatan maupun laba yang diperoleh perusahaan dapat terus meningkat. 


\section{DAFTAR PUSTAKA}

Aprianton, Rico. 2008. Penilaian Kinerja Keuangan PT. Mayora Indah Tbk melalui Analisis Laporan keuangan dengan Metode Analisis Rasio. Undergraduate thesis, Universitas Kristen Maranatha.

Caesario, Emanuel. B. (2016). Wajib Pajak Real Estate Ikut Tax Amnesty. http://finansial.bisnis.com/read/20161130/9/607695/baru-202-wajib-pajak-realestate-ikut-tax-amnesty diakses tanggal 03 Desember 2016 pukul 11.25 Wita.

Direktorat Jendral Pajak. (2016). Pembiayaan Negara 70 persen dari pajak. di akses melalui www.pajak.go.id/content/pembiayaan-negara-70-persen-dari-pajak di akses pada tanggal 06 Oktober 2016 pukul 20.55 Wita.

Direktorat Jendral Pajak. 2016. Dana Tax Amnesty Periode Pertama, di akses melalui http://pajak.go.id/statistik-amnesti pada tanggal 25 november 2016 pukul 15.45 pm

Erlita (2010), Analisis Pengaruh Reformasi Pajak Badan Tahun 2008 Terhadap Kinerja Keuangan Perusahaan Yang Terdaftar Di BEI.

Ferdinand, Agusty. 2006. Metode Penelitian Manajemen : Pedoman Penelitian Untuk Penulisan Skripsi, Tesis dan Disertasi Ilmu Manajemen. Edisi Pertama. Semarang: Badan Penerbit Universitas Diponegoro

Ginting, Monalisa BR. 2010. Pengaruh Karakteristik Perusahaan Terhadap Kelengkapan Pelaporan Keuangan Pada Perusahaan Barang Konsumsi Yang Terdaftar Di Bursa Efek Indonesia. Medan : Universitas Sumatera Utara.

Hanafi, Mamduh M. \& Halim, Abdul. 2016. Analisis Laporan Keuangan, Edisi Kelima. Yogyakarta : UPP STIM YKPN 2003, “Analisis Laporan Keuangan. Yogyakarta: UPP-AMP-YKPN.

Harahap, Syafri S. 1998. Analisa Kritis Atas Laporan Keuangan. Jakarta: Raja Grafindo Persada.

Helfert, E.A. 1997. Teknik Analisis Keuangan. Penerjemah Herman Wibowo. Edisi Kedelapan. Jakarta : Erlangga

Husnan, Suad. 2003. Manajemen Keuangan Teori dan Penerapan (keputusan Jangka Pendek), Edisi keempat. Yogyakarta: BPFE.

Idris, Muhammad. 2016. Akhir Periode 1 Tax Amnesty. di akses melalui https://finance.detik.com/berita-ekonomi-bisnis/d-3310989/akhir-periode-i-taxamnesty-repatriasi-rp-137-t-uang-tebusan-rp-972-t pada tanggal 24 November 2016, pukul $17.40 \mathrm{pm}$ 
Jogiyanto. (2007). Metodologi Penelitian Bisnis: Salah Kaprah dan PengalamanPengalaman. Cetakan pertama. Yogyakarta: BPFE.

Junaidi. 2010. Titik Persentase Distribusi $\mathrm{t}$ d.f $=1-200$ diakses melalui https://junaidichaniago.files.wordpress.com/2010/tabel-t.pdf Pada tanggal 03 Januari 2017.

Ministry of Finance Republic of Indonesia. 2016. Anggaran pendapatan dan belanja negara tahun 2016. Diakses pada 06 Oktober 2016 pukul 20.49 Wita melalui www.kemenkeu.go.id/en/node/47651

Munawir.2004. Analisa Laporan Keuangan. Yogyakarta : Liberty

Nazir, Mohammad. 2005. Metode Penelitian. Jakarta: Ghalia Indonesia

Ngadiman, Huslin Daniel. 2015. Pengaruh Sunset Policy,Tax Amnesty, dan Sanksi Pajak Terhadap Kepatuhan Wajib Pajak”, Jurnal Akuntansi/Volume XIX, No.02, Mei 2015.

Nugroho. 2004. Analisis Perbedaan Kinerja Keuangan Perusahaan Manufaktur Sebelum Dan Sesudah Diterapkannya Undang-Undang Pajak Penghasilan Tahun 2000.

Ragimun. 2014. Analisis Implementasi Pengampunan Pajak (Tax Amnesty) di Indonesia, Badan Kebijakan Fiskal Kemenkeu RI.

Shanti, J.C. 2010. Analisis Kinerja Keuangan Perusahaan-Perusahaan Manufaktur Yang Terdaftar Di Bursa Efek Indonesia Sebelum dan Sesudah Pembayaran Deviden Kas. Jurnal Akuntansi dan Manajemen Vol. 21 No. 1 April 2010 Hal. 45-48

Sucipto. 2003. Penilaian Kinerja Keuangan. Jurnal Akuntansi, Program Sarjana Universitas Sumatera Utara, Medan.

Sugiyono. (1999). Metode Penelitian Bisnis. Bandung: Alfabeta.

Sunoto. 2011. Pengaruh Perubahan Tarif Pajak Terhadap Kinerja Keuangan Perusahaan Manufaktur Yang Go Public Di Bursa EfeK Indonesia Periode 2007-2010. Universitas Negeri Semarang.

Weston, J.F dan Copeland T.E. 2010. Manajemen Keuangan Edisi Revisi. Tanggerang : Binarupa Aksara Publisher

.(2016). Undang-Undang Republik Indonesia Nomor 11 Tahun 2016 Tentang Pengampunan Pajak. Diakses melalui website http://itjen.ristekdikti.go.id/wpcontent/uploads/2015/12/UU-Tax-Amnesty-No-11-tahun-2016.pdf. No. 131, 2016. Pada tanggal 13 September 2016 pukul 16.20 Wita.

.(2016). Peraturan Menteri Keuangan Republik Indonesia Nomor 118/PMK. 03/2016 Tentang Pelaksanaan Undang-Undang No. 11 Tahun 2016 Tentang 
Pengampunan Pajak. Diakses melalui http://www.pajak.go.id/sites/default/ files/info-pajak/PMK-118-PMK 03 -2016.pdf . pada tanggal 13 September 2016 pukul 16.35 Wita.

.(2016) Bagaiaman Angkutan Publik Menyikapai Tax Amnesty. Diakses melalui http://www.amnestipajak.info/bagaimana-akuntan-publik-ap-menyikapi-taxamnesty.html pada tanggal 03 Oktober 2016 pukul 20.55 Wita.

.(2016). Hand Out Materi Amnesti Pajak. Diakses melalui website www.pajak.go.id/sites/default/fils/Handout-Materi-Amnesti-pajak.pd. Pada Tanggal 20 Oktober 2016, pukul 17. 15 Wita

www.idx.co.id

$\underline{\text { www.sahamok.com }}$

www.pajak.go.id 